\title{
Vascular Endothelial Growth Factor Directly Inhibits Primitive Neural Stem Cell Survival But Promotes Definitive Neural Stem Cell Survival
}

\author{
Tamaki Wada, ${ }^{1}$ Jody J. Haigh, ${ }^{2}$ Masatsugu Ema, ${ }^{2}$ Seiji Hitoshi, ${ }^{1}$ Radha Chaddah, ${ }^{1}$ Janet Rossant, ${ }^{2}$ Andras Nagy, ${ }^{2}$ and \\ Derek van der Kooy ${ }^{1}$ \\ ${ }^{1}$ Department of Medical Genetics and Microbiology, University of Toronto, Toronto, Ontario, Canada M5S 3E1, and ${ }^{2}$ Samuel Lunenfeld Research Institute, \\ Mount Sinai Hospital, Toronto, Ontario, Canada M5G 1X5
}

\begin{abstract}
There are two types of neural stem cells (NSCs). Primitive NSCs [leukemia inhibitory factor (LIF) dependent but exogenous fibroblast growth factor (FGF) 2 independent] can be derived from mouse embryonic stem (ES) cells in vitro and from embryonic day 5.5 (E5.5) to E7.5 epiblast and E7.5-E8.5 neuroectoderm in vivo. Definitive NSCs (LIF independent but FGF2 dependent) first appear in the E8.5 neural plate and persist throughout life. Primitive NSCs give rise to definitive NSCs. Loss and gain of functions were used to study the role of vascular endothelial growth factor (VEGF)-A and its receptor, Flk1, in NSCs. The numbers of Flk1 knock-out mice embryo-derived and ES cell-derived primitive NSCs were increased because of the enhanced survival of primitive NSCs. In contrast, neural precursor-specific, Flk1 conditional knock-out mice-derived, definitive NSCs numbers were decreased because of the enhanced cell death of definitive NSCs. These effects were not observed in cells lacking Flt1, another VEGF receptor. In addition, the cell death stimulated by VEGF-A of primitive NSC and the cell survival stimulated by VEGF-A of definitive NSC were blocked by Flk1/Fc-soluble receptors and VEGF-A functionblocking antibodies. These VEGF-A phenotypes also were blocked by inhibition of the downstream effector nuclear factor $\kappa B(\mathrm{NF}-\kappa \mathrm{B})$. Thus, both the cell death of primitive NSC and the cell survival of definitive NSC induced by VEGF-A stimulation are mediated by bifunctional NF- $\kappa$ B effects. In conclusion, VEGF-A function through Flk1 mediates survival (and not proliferative or fate change) effects on NSCs, specifically.
\end{abstract}

Key words: neural stem cell; embryonic stem cell; VEGF-A; cell survival/death; neurosphere; NF- $\kappa \mathrm{B}$

\section{Introduction}

Neural stem cells (NSCs), which exist in the embryonic brain germinal zone (and its postnatal remnant), can be expanded and their progeny induced to differentiate into neurons and glia in vitro and in vivo under the control of growth factors (Gage, 2000; van der Kooy and Weiss, 2000; Seaberg and van der Kooy, 2003). There are two major populations of NSCs: an early primitive NSC (p-NSC) population that gives rise to a later definitive NSC (dNSC) population during embryonic development (Hitoshi et al.,

Received Sept. 30, 2005; revised May 1, 2006; accepted May 2, 2006.

This work was supported by the Canadian Institutes of Health Research and the Canadian Stem Cell Network.

Correspondence should be addressed to either Tamaki Wada or Derek van der Kooy, Department of Medical Genetics and Microbiology, University of Toronto, \#1102 Donnelly CCBR, 160 College Street, Toronto, Ontario, Canada M5S 3E1.E-mail: tamaki.wada@utoronto.ca or derek.van.der.kooy@utoronto.ca.

T. Wada's and J. Rossant's present address: Program in Developmental Biology, The Hospital for Sick Children, Room 13-315, TMDT Building, 101 College Street, Toronto, Ontario, Canada M5G 1 L7.

J. J. Haigh's present address: Department for Molecular Biomedical Research, Flanders Interuniversity Institute for Biotechnology (VIB), Ghent University, Vascular Cell Biology Unit, Technologiepark 927, B-9052 Ghent, Zwijnaarde, Belgium.

M. Emas's present address: Department of Anatomy and Embryology, Institute of Basic Medical Sciences, Division of Developmental Technology, Laboratory Animal Resource Center, University of Tsukuba, 1-1-1 Tennodai, Tsukuba, Ibaraki, 305-8575, Japan.

S. Hitoshi's present address: Division of Neurobiology and Bioinformatics, National Institute for Physiological Sciences, Aichi 444-8585, Japan.

DOI:10.1523/JNEUROSCI.0526-06.2006

Copyright $\odot 2006$ Society for Neuroscience $\quad 0270-6474 / 06 / 266803-10 \$ 15.00 / 0$
2004). p-NSCs can be derived from undifferentiated embryonic stem (ES) cells and also can be isolated from the embryonic day 5.5 (E5.5) epiblast stage until the E8.5 neuroectoderm in mouse embryos (Hitoshi et al., 2004). d-NSCs can be derived from p-NSCs in vitro and are present in the E8.5 neural tube and persist into the senescent adult brain (Hitoshi et al., 2004). Both types of NSCs have similar potential to produce secondary and tertiary clonal colonies (neurospheres), and their clonal progeny can differentiate into neurons and glial cells. p-NSCs require exogenous leukemia inhibitory factor (LIF) for their maintenance and proliferation in vitro, but exogenous fibroblast growth factor (FGF) 2 is not required. In contrast, d-NSCs require only FGF2 or epidermal growth factor (EGF) (and not LIF) for their maintenance and proliferation (Hitoshi et al., 2004).

Vascular endothelial growth factor (VEGF) is known to be essential for both angiogenesis and hematopoiesis (Shalaby et al., 1995, 1997; Ema et al., 2003). Early hematopoietic cells and angioblasts express a number of genes in common, including type-1 VEGF receptor (commonly known as Flt1) and $K d r$ (commonly known as type-2 VEGF receptor or Flk1) (Dumont et al., 1995; Fong et al., 1996). Only mutation of Flk1 leads to the complete absence of hematopoietic and endothelial cell differentiation in vivo (Shalaby et al., 1995). A close anatomical relationship between proliferating hippocampal neural progenitor cells and pro- 
liferating endothelial cells has been noted (Palmer et al., 2000; Jin et al., 2002; Wurmser et al., 2004). Moreover, Flk1 is expressed in the adult rat forebrain subependymal germinal zone and the hippocampal subgranular zone (Jin et al., 2002). Indeed, VEGF effects on neural development and regeneration have been reported (Jin et al., 2002; Fabel et al., 2003; Sun et al., 2006).

Although previous reports have suggested both a direct role for VEGF-A signaling in neural development (Palmer et al., 2000; Jin et al., 2002; Schanzer et al., 2004) and an indirect role via endothelial cells in NSC development (Shen et al., 2004), the function of VEGF-A on NSCs is still unknown. In this report, we investigated the functions of VEGF-A on the cells at the top of the neural lineage hierarchy, the p-NSCs and d-NSCs. Both gain and loss of function manipulations demonstrate that VEGF-A signaling inhibits the survival of p-NSCs but enhances the survival of d-NSCs. The opposite effects of VEGF-A signaling on p-NSCs and d-NSCs emphasize again the unique nature of these two distinctive NSC populations.

\section{Materials and Methods}

ES cell-derived p-NSC assays/ES cell dissociation culture. The R1 ES cell lines (Flk1 ${ }^{+/+}, \mathrm{Flk1}^{-/-}$, and Flt1 ${ }^{-/-}$cells) (Shalaby et al., 1995, 1997) were grown on mitotically inactive fibroblast feeder layers and maintained in DMEM plus 15\% FCS culture medium containing LIF (1000 $\mathrm{U} / \mathrm{ml}$ ) at low passage numbers $(6-11)$, as described previously (Tropepe et al., 2001). ES cells were trypsinized and plated in serum-free media at 10 cells $/ \mu \mathrm{l}$ in 24 -well culture plates in the presence of LIF $(1000 \mathrm{U} / \mathrm{ml})$ for $7 \mathrm{~d}$. Neurospheres (diameter, $>100 \mu \mathrm{m}$ ) were counted and then some were passaged by mechanical dissociation and plated at $10 \mathrm{cells} / \mu \mathrm{l}$ in the serum-free media with FGF2 (human recombinant; Sigma, St. Louis, MO) and B27 (Invitrogen, Carlsbad, CA) for $7 \mathrm{~d}$ (Tropepe et al., 2001). For single-sphere passaging, each neurosphere was dissociated individually and plated in the serum-free media with FGF2 and B27 for $7 \mathrm{~d}$. Differentiation of neuron and glia from p-NSC-derived neurospheres were described in a previous report (Tropepe et al., 2001). For short-term survival assays, dissociated undifferentiated ES cells were plated on the polyornithine-coated plates at 10 cells/ $\mu$ l to assay the p-NSCs that default from undifferentiated ES cells and were incubated in serum-free media for 4 or $24 \mathrm{~h}$. For undifferentiated ES cell cultures, dissociated undifferentiated ES cells were plated on gelatin-coated chamber slides in DMEM plus $15 \%$ FCS culture medium containing LIF $(1000 \mathrm{U} / \mathrm{ml})$ at $10 \mathrm{cells} / \mu \mathrm{l}$ for 4 or $24 \mathrm{~h}$. Cells were fixed with $4 \%$ paraformaldehyde (PFA) and stained with a Nestin antibody (Chemicon, Temecula, CA) and Hoechst 33258 (Roche, Welwyn Garden City, UK) for nuclear staining. To inhibit VEGF-A activity, $5 \mu \mathrm{g} / \mathrm{ml}$ VEGF-A antibody (R \& D Systems, Minneapolis, MN) and $100 \mathrm{ng} / \mathrm{ml}$ recombinant mouse VEGFR2 (Flk1)/Fc chimera ( $\mathrm{R} \& \mathrm{D}$ Systems) were added at the beginning of neurosphere culture in the absence or presence of $100 \mathrm{ng} / \mathrm{ml}$ human recombinant VEGF-A.

Embryonic neurosphere assay. CD1 mice (Charles River, Montreal, Quebec, Canada), Flk1 ${ }^{-1-}$ mice (Shalaby et al., 1997), and $\mathrm{Nes}^{\mathrm{Cre}}$; Flk1 ${ }^{-l-}$ mice (Haigh et al., 2003) were used in these studies. Midday of the plugged day was termed E0.5. Prospective head regions from E7.5 mouse embryos at late primitive streak stage or early headfold stage were excised and treated with trypsin. Usually, 2000-3000 viable cells were collected from each E7.5 embryo. The head primordia from E9.5 embryos were dissected, and anterior neural tube tissue was teased gently away from the surrounding head mesenchyme and overlying epidermal ectoderm. E14.5 mice were dissected for removal of the cerebral hemispheres. The collected tissue was dissociated mechanically in serum-free medium into a cell suspension. Dissociated cells were plated at $10 \mathrm{cells} / \mu \mathrm{l}$ in 24-well culture plates in serum-free media with LIF and B27 for E7.5 cells and with FGF2 for E9.5 and E14.5 cells (Hitoshi et al., 2004), with or without VEGF-A (recombinant human; R \& D Systems) for $7 \mathrm{~d}$. Other combinations of genotyping of embryonic Flk $1^{-/-}$mice was performed by genomic PCR from unused tissues from each embryo. Primary or secondary neurosphere from E14.5 mice were passaged by mechanically dissociation into single cells and then culture at 10 cells $/ \mu \mathrm{l}$ in serum-free media with FGF2 and B27 for $7 \mathrm{~d}$ to assay secondary or tertiary neurospheres, respectively. Differentiation of neuron and glia from NSCderived neurospheres was performed as described in a previous report (Tropepe et al., 1999). Inhibition of VEGF-A activity in E14.5 d-NSC neurosphere culture was done exactly as described above for ES-derived p-NSC culture.

Adult neurosphere/acute dissociation assays. CD1 mice were used in these studies. Mice were killed via cervical dislocation, and their brains were aseptically excised. Medial and lateral portions of the lateral ventricle subependyma were dissected from both hemispheres and then cut into $1 \mathrm{~mm}^{3}$ pieces in oxygenized artificial CSF. The tissue was digested with $1.33 \mathrm{mg} / \mathrm{ml}$ trypsin, $0.67 \mathrm{mg} / \mathrm{ml}$ hyaluronidase, and $0.2 \mathrm{mg} / \mathrm{ml}$ kynurenic acid to dissociate the tissue at $37^{\circ} \mathrm{C}$ for $1 \mathrm{~h}$. Tissue was transferred to serum-free media containing $0.7 \mathrm{mg} / \mathrm{ml}$ trypsin inhibitor (Ovamucoid; Roche) and triturated with a fire-polished Pasteur pipette. Dissociated cells were plated at 10 cells/ $\mu \mathrm{l}$ in 24 -well culture plates in serum-free media with FGF2 and EGF in the presence or absence of VEGF-A for $7 \mathrm{~d}$. The VEGF-A inhibitor SU1498 (Calbiochem, La Jolla, CA) was diluted with DMSO. Neurospheres bigger than $100 \mu \mathrm{m}$ in diameter were collected after $7 \mathrm{~d}$ and plated on Matrigel-coated dishes in $1 \%$ FBS-containing media for $7 \mathrm{~d}$. For the acute forebrain subependymal germinal zone dissociation from $\mathrm{Nes}{ }^{\mathrm{Cre}} ; \mathrm{Flk}^{-1-}$ and control Nes ${ }^{\mathrm{Cre}}$; $\mathrm{Flk} 1^{+/-}$mice, the dissociated cells were plated on Matrigel-coated dishes and incubated in serum-free media for overnight. The cells were fixed with 4\% PFA and stained with either anti-mouse Ki-67 antibody (PharMingen, Franklin Lakes, NJ) or an in situ cell death detection kit (Roche).

Nuclear factor $\kappa B$ inhibitor treatment. SC-514 (100 $\mu \mathrm{M}$; Calbiochem) or JSH-23 (100 $\mu \mathrm{M}$; Calbiochem) were added to ES-derived p-NSC or mouse E14.5 d-NSC neurosphere cultures for $7 \mathrm{~d}$ in the presence or absence of $100 \mathrm{ng} / \mathrm{ml}$ human recombinant VEGF-A.

Reverse transcription-PCR from bulk spheres. Total RNA was isolated using the RNeasy extraction kit mini (Qiagen, Hilden, Germany) and 1 $\mu \mathrm{g}$ was used to synthesize cDNA with oligo-d(T)12-18 primers and MuMLV reverse transcriptase (Superscript II; Roche) at $42^{\circ} \mathrm{C}$ for $1 \mathrm{~h}$. For PCR, $1 \mu \mathrm{l}$ of cDNA was used to amplify specific sequences for Nestin (forward, 5' -ATTTTGACAGATGCCCATGA-3'; reverse, 5' -AGGCTCAGCACTGTCCTGAG-3'), Soxl (forward, 5'-CCTCGGATCTCTGGTCAAGT-3'; reverse, 5' -TACAGAGCCGGCAGTCATAC-3'), Brachyury (forward, $5^{\prime}$-AGTATGAACCTCGGATTCAC-3' ; reverse, 5' -CCGGTTGTTACAAGTCTCAG-3'), Flk1 (forward, 5'-TCAGTCATTATCTCCAGAACAG-3'; reverse, 5' -AATCAAATGTGGCTACTTCCGG-3'), VEGF-A (forward, 5'-GACCCTGGTGGACATCTTCCAGGA-3'; reverse, 5' GGTGAGAGGTCTAGTTCCCGA-3'), Flt1 (forward, 5'-GGACTATACGATCTTGCTGG-3'; reverse, 5'-GAGAGTCAGCCACCACCA-3'), glyceraldehyde-3-phosphate dehydrogenase (GAPDH) (forward, 5' TCATTGACCTCAACTACATGGT-3'; reverse, $5^{\prime}$-AATGCCAAAGTTGTCATGGATG- $3^{\prime}$ ), and nuclear factor $\kappa \mathrm{B}$ (NF- $\kappa$ B) (forward, $5^{\prime}$-GACATGGCTGCCAACTGGCAGGTA-3'; reverse, 5' -CTAAATTTTGCCTTCAATAGGTCC-3').

Single-sphere reverse transcription-PCR. Single-sphere reverse transcription-PCR (RT-PCR) followed the OneStep RT-PCR kit (Qiagen) protocol. Total RNA was extracted from single clonal sphere colonies and eluted in $15 \mu \mathrm{l}$ of $\mathrm{H}_{2} \mathrm{O}$. One microliter of the RNA preparation was used for quantification, and the remainder (containing $\sim 0.1 \mu \mathrm{g}$ of RNA) was used for RT-PCR.

Statistical analyses. Results are expressed as mean values \pm SEM. ANOVA or $t$ tests were used to analyze data as appropriate. Significant ANOVA factors were followed by post hoc comparisons of individual means using Tukey's method where appropriate. Significance was defined as two-tailed $p<0.05$.

\section{Results}

Lack of VEGF-A signaling enhances primitive neural stem cell numbers

Initially, we examined the expression of Flk1 and VEGF-A in undifferentiated ES cells by RT-PCR. Wild-type Flk $1^{+/+}$undifferentiated ES cells showed weak expression of Flk1 mRNA, and 
Table 1. Loss of Flk1 does not affect the differentiation of neurons and glia from the progeny of either p-NSCs derived from Flk1 ${ }^{-1-}$ ES cells or d-NSCs derived from E14.5 Nes ${ }^{\text {Cre }}$;Flk1 ${ }^{-/-}$conditional knock-out mice

\begin{tabular}{lll}
\hline & MAP2 $^{+}$neuron $(n)$ & GFAP $^{+}$astrocyte $(n)$ \\
\hline p-NSC Flk1 $^{+/+}$ & $2.5 \pm 0.6 \%(4)$ & $17.4 \pm 5.9 \%(4)$ \\
p-NSC Flk1 $^{-1-}$ & $2.2 \pm 0.8 \%(4)$ & $18.7 \pm 6.0 \%(4)$ \\
d-NSC Flk1 $^{+/+}$ & $3.8 \pm 1.1 \%(5)$ & $43.6 \pm 5.7 \%(5)$ \\
d-NSC Flk1 $^{-1-}$ & $3.4 \pm 0.9 \%(4)$ & $38.3 \pm 7.6 \%(4)$ \\
\hline
\end{tabular}

The proportions of microtubule-associated protein $2\left(\mathrm{MAP}^{+}\right)^{+}$and $\mathrm{GFAP}^{+}$cells were calculated from total cells.

as expected, undifferentiated Flk1 ${ }^{-/-}$ES cells had no Flk1 expression (Fig. 1A). Undifferentiated Flk $1^{+/+}$and Flk1 ${ }^{-/-}$ES cells each expressed VEGF-A mRNA and another VEGF receptor, Flt1 mRNA (Fig. 1A). We tested Flk1 function in the clonal formation of p-NSC-derived neurospheres by using Flk1-deficient ES cells in which the endogenous Flk1 gene is replaced by a $\beta$-galactosidase (lac Z) gene. Flk1 ${ }^{+/-}$and Flk1 ${ }^{-/-}$ES cells have one and two alleles replaced by the lac $Z$ gene, respectively (Shalaby et al., 1995; Ema et al., 2003). Undifferentiated ES cells were suspended in LIF-containing, serum-free media conditions under which clonal p-NSC-derived neurospheres arose after $7 \mathrm{~d}$ (Tropepe et al., 2001). Interestingly, Flk $1^{-1-}$ ES cells produced a threefold greater number of sphere colonies than the control Flk $1^{+/+}$ES cells at the standard starting clonal cell density (10 cells $/ \mu \mathrm{l})$ and at a lower density $(1 \mathrm{cell} / \mu \mathrm{l})$ (Fig. $1 B)$. Flk $1^{+/-}$ p-NSC spheres formed in similar numbers to Flk $1^{+/+}$p-NSC spheres (data not shown). In contrast, both the numbers (Fig. $1 B$ ) and diameters (Flt1 ${ }^{+/+}, 211 \pm 36 \mu \mathrm{m}$; Flt $1^{-/-}, 226 \pm 21$ $\left.\mu \mathrm{m} ; t_{(5)}=0.4 ; p>0.5\right)$ of $\mathrm{p}-\mathrm{NSC}$ clonal spheres derived from Flt1 knock-out ES (Flt1 ${ }^{-/}$) cells (Fong et al., 1999) were not different from the p-NSC clonal spheres derived from the control wildtype R1 ES cells. This suggests that VEGF-A signaling specifically through Flk1 receptors (not Flt1) regulates p-NSC formation. Moreover, when spheres were plated on Matrigel-coated dishes under differentiation conditions, the numbers of neurons and glial cells produced by both Flk $1^{+/+}$and Flk $1^{-/-}$p-NSC spheres were similar (Table 1). These data suggest that loss of Flk1 expression produces only a $\mathrm{p}$-NSC increase with no effect on $\mathrm{p}$-NSC multipotency. Furthermore, Flk $1^{+/+}$and Flk $1^{-/-}$p-NSC sphere diameters were similar (Flk1 ${ }^{+/+}, 205 \pm 12 \mu \mathrm{m}$; Flk1 ${ }^{-/-}, 212 \pm$ $\left.17 \mu \mathrm{m} ; t_{(5)}=0.4 ; p>0.5\right)$, suggesting the Flk1 deficiency affects the p-NSC itself and not the proliferation of its neural progenitor progeny that comprise most of the cells in each sphere.

An initial gene expression characterization of the bulk sphere colonies was performed using RT-PCR. Flk1 mRNA expression was observed only in Flk1 ${ }^{+/+}$and not in Flk $1^{-/-}$p-NSC spheres (Fig. 1C). Flk $1^{-1-}$ p-NSC spheres expressed Brachyury mRNA (a mesodermal marker), in addition to the neural markers Nestin and Sox1, whereas wild-type Flk $1^{+/+}$p-NSC spheres expressed only Nestin and Sox1 (Fig. 1C). This result suggests that Flk1 ${ }^{-/-}$ p-NSC colonies may have broader non-neural potential than Flk $1^{+/+}$p-NSCs. Nevertheless, even wild-type p-NSCs have the ability to form non-neural cell types when integrated into embryos derived from blastocyst chimeras (Tropepe et al., 2001). Indeed, p-NSC colonies that arise from wild-type Flk $1^{+/+} \mathrm{ES}$ cells cultured at high density $(100$ cells/ $\mu \mathrm{l})$ also show weak expression of Brachyury mRNA (Fig. 1D).

The Brachyury mRNA expression in wild-type p-NSC colonies derived from high-cell-density wild-type Flk $1^{+/+}$cultures may be explained in two ways. First, clonal p-NSCs (which have the potential to produce non-neural cells and express Brachyury when placed back into the high-cell-density blastocyst) (Tropepe et al., 2001) also may reveal this potential in high-density culture in vitro as well (present results). Second, high-density ES cultures (although done in neural-inducing, serum-free media conditions) may produce culture conditions similar to embryoid body cultures, in which separate ES cells aggregate to produce the different cell lineages of all three germ layers. To test these clonal versus nonclonal possibilities, we cultured Flk1 ${ }^{+/+}$and Flk1 ${ }^{-/-}$ ES cells at low densities at which only clonal p-NSC colonies formed (Tropepe et al., 2001) and then analyzed clonal p-NSC sphere colonies by RT-PCR. Although all the clonal Flk $1^{+/+}$ p-NSC spheres expressed only Nestin (16 of 16) and never Brachyury (0 of 16), some clonal Flk $1^{-1-}$ p-NSC spheres expressed Brachyury (6 of 16) in addition to Nestin (16 of 16) (Fig. $1 E)$. This suggests that the potential to produce non-neural cells is enhanced in clonal Flk1 ${ }^{-1-}$ p-NSC compared with clonal Flk1 ${ }^{+/+}$p-NSC colonies.

We asked whether the increase in clonal p-NSC spheres formed from Flk1 ${ }^{-/-}$compared with Flk $1^{+/+}$ES cells was a cell-autonomous effect of the mutation in the sphere-forming cells. Yellow fluorescence protein (YFP)-expressing Flk1 wildtype ES cells, which show the same p-NSC sphere-forming potential as nonfluorescent Flk1 ${ }^{+/+}$ES cells, were cocultured at clonal densities with Flk1 ${ }^{+/+}$or Flk1 ${ }^{-/-}$ES cells, and then clonal YFP p-NSC colonies were counted. YFP-expressing p-NSC sphere numbers were identical in the coculture with Flk1 ${ }^{-/-} \mathrm{ES}$ or Flk $1^{+/+}$ES cells (Fig. $1 F$ ). Moreover, the increase of non-YFP fluorescent Flk1 ${ }^{-/-}$p-NSC spheres remained threefold higher than the number of non-YFP fluorescent Flk ${ }^{+/+}$p-NSC spheres (Fig. 1F). These data suggest that the Flk $1^{-/-}$mutation works cell autonomously in the p-NSC-forming cell.

\section{Flk $1^{-/-}$primitive neural stem cells show less cell death than control Flk1 ${ }^{+/+}$primitive neural stem cells}

To test whether the initial fate change from single ES cells to single p-NSCs was affected by the Flk1 mutation, we observed Nestin expression $4 \mathrm{~h}$ after removal of serum and all growth factors from the ES cells, a time at which wild-type ES cells already have begun to express Nestin and default to a p-NSC fate (Tropepe et al., 2001). No Nestin expression was observed in undifferentiated ES cells (Fig. 2C). After $4 \mathrm{~h}$ in the minimal, neural default media, equal numbers of Nestin-positive cells were found in the Flk1 ${ }^{+/+}$and Flk1 ${ }^{-/-}$cultures, although a few Nestin-negative cells also were present (Fig. 2B). By $24 \mathrm{~h}$ in the minimal conditions, many wild-type p-NSC have begun to die (Tropepe et al., 2001). Indeed, by $24 \mathrm{~h}$, fewer viable cells were found in the Flk $1^{+/+}$than in the Flk ${ }^{-/-}$cultures (and almost all of this cell death in the Flk1 ${ }^{-1-}$ cultures involved Nestin ${ }^{+}$cells) (Fig. $2 B, C$ ). This result suggests that Nestin-positive cells that are biased to neural lineage in Flk1 $1^{-/-}$culture are surviving better than the cells that are less biased to neural lineage in Flk1 ${ }^{+/+}$ culture. Nestin expression is observed in not only p-NSCs but also neural progenitors. However, the vast majority of dissociated cells after 4 or $24 \mathrm{~h}$ in culture are p-NSCs because this time in culture is too short for them to proliferate and differentiate into neural progenitors. To test whether this survival effect also occurred in undifferentiated ES cells, undifferentiated Flk $1^{+/+}$and Flk1 ${ }^{-1-}$ ES cells were plated on gelatin-coated chamber slides for 4 and $24 \mathrm{~h}$ in normal undifferentiated ES culture media. In fact, there were no survival differences between Flk $1^{+/+}$and Flk1 ${ }^{-/-}$ ES cells in the undifferentiated state (Fig. $2 A$ ). These results suggest that in the absence of Flk1, there is no effect on undifferentiated ES cells nor on the rapid default of ES cells to p-NSCs, but 
A undifferentiated ES cells

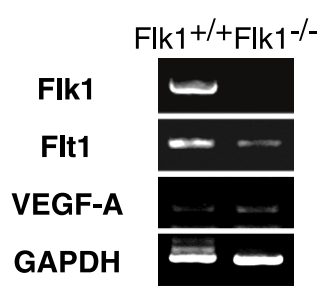

C

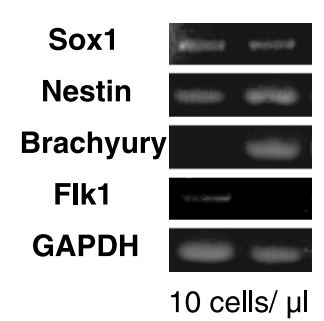

B
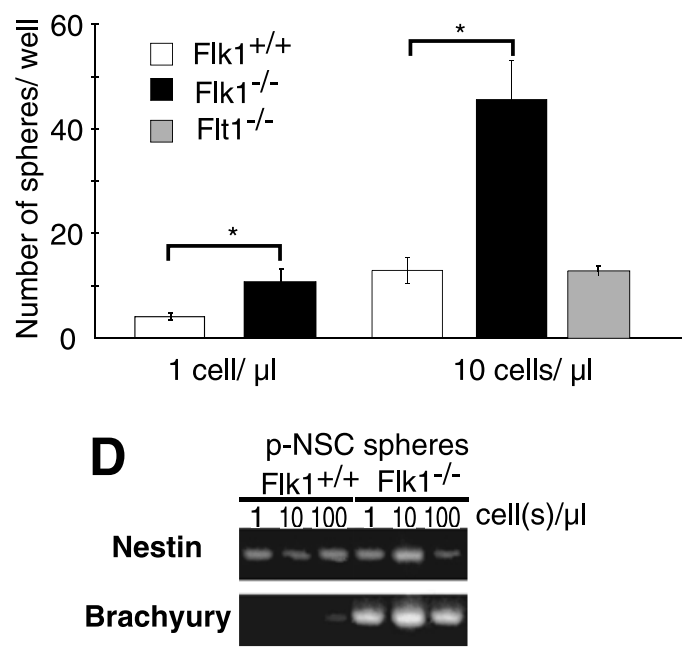

E

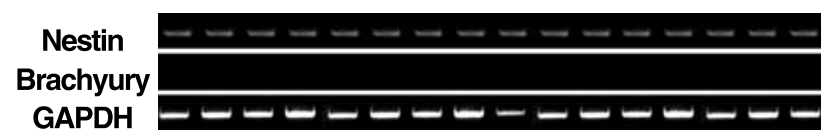

$\mathrm{Flk} 1^{-/-}$

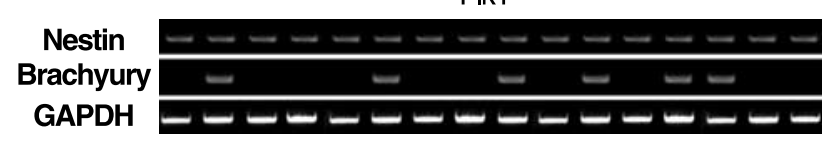

$\mathbf{F}$

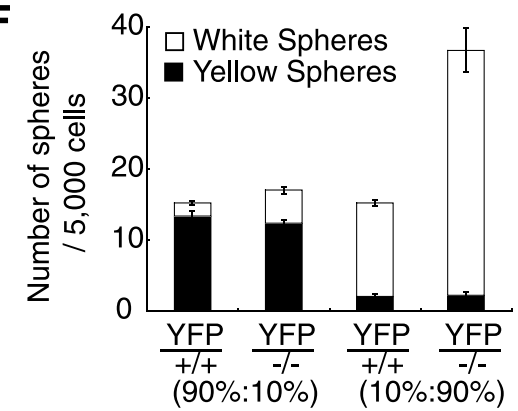

Figure 1. A, Undifferentiated Flk $1^{+/+}$(but not Flk $1^{-/-}$) ES cells express low levels of Flk1 mRNA. Both Flt1 and VEGF-A mRNA expression also are observed in both of the undifferentiated ES cell lines. GAPDH was used as a universal control. $B$, The numbers of Flk $1^{-1-}$ p-NSC spheres were three times greater than the numbers of Flk ${ }^{+/+} \mathrm{p}$-NSC spheres at starting ES cell densities of both 1 cell $/ \mu l\left(t_{(6)}=2.2 ; p<0.05\right)$ and 10 cells $/ \mu l\left(t_{(6)}=3.9 ; p<0.05\right)$. The number of Flt $1^{-1-} p$-NSC spheres was similar to Flt $1^{+/+} p$-NSC spheres $\left(t_{(5)}=0.4 ; p>0.5\right)$. C, Bulk Flk1 $1^{-1-} p$-NSC spheres expressed the mesodermal marker gene Brachyury, which is never expressed by Flk $1^{+/+} \mathrm{p}$-NSC spheres. Expression of the NSC markers Sox1 and Nestin was observed in both Flk1 $1^{+/+}$and Flk1 $1^{-/-}$p-NSC spheres. Flk1 expression was observed in these Flk1 $1^{-/-}$p-NSCs then do survive better than Flk1 ${ }^{+/+}$ p-NSCs.

\section{VEGF-A directly decreases primitive neural stem} cell numbers

To investigate gain of Flk1 function effects on p-NSCs, VEGF-A was added to our minimal neural differentiation cultures. Flk1 is stimulated by VEGF-A in several kinds of cells during development (Cross et al., 2003). When undifferentiated ES cells were cultured with VEGF-A, p-NSC sphere numbers decreased significantly (Fig. 3A). However, VEGF-A treatment of these wild-type p-NSC spheres did not induce Brachyury mRNA expression and did not change Nestin and Flk1 mRNA expression (Fig. 4B). To check the specificity of VEGF-A action, two different VEGF-A inhibitors were added separately to p-NSC sphere cultures. The ability of VEGF-A to decrease p-NSC numbers was blocked by both of the VEGF-A antibodies and the Flk1/Fc chimeric soluble receptors (Fig. $3 A$ ). These results indicate that VEGF-A acts specifically on the Flk1 receptor in suppressing p-NSC formation. Moreover, VEGF-A inhibitors also increased p-NSC sphere numbers even in the absence of VEGF-A (Fig. $3 A$ ). This suggests that endogenous VEGF-A is released by the cells in culture and that the inhibitors are overcoming this endogenous effect.

Lack of VEGF-A signaling enhances primitive neural stem cell numbers in vivo

Flk1 conventional knock-out mice (Flk $1^{-1-}$ mice) die at around E8.5 (Shalaby et al., 1995). Although that is the earliest stage at which d-NSC can be isolated during development (Tropepe et al., 2001), p-NSCs can be isolated from the epiblast at E7.5 (Hitoshi et al., 2004). p-NSCs were isolated from E7.5 Flk1 ${ }^{-/-}$and control wild-type $\left(\mathrm{Flk}^{+/+}\right)$mice and cultured in LIF-containing media for $7 \mathrm{~d}$. p-NSC-derived neurosphere numbers from Flk1 ${ }^{-1-}$ epiblasts showed a $60 \%$ increase compared with numbers of p-NSCs derived from control Flk1 ${ }^{+/+}$epiblasts (Fig. $3 B$ ). Thus, more p-NSCs are derived from both Flk1 ${ }^{-/-}$ES cells and Flk1 ${ }^{-I-}$ embryos compared with wild-type controls. Together, these results imply that Flk1 acts to suppress p-NSC numbers.

\section{Addition of VEGF-A increases the numbers of definitive} neural stem cells

d-NSCs have formed in the E8.5 neural tube over a $1 \mathrm{~d}$ period from the p-NSCs of the epiblast and neural plate (Hitoshi et al., 2004). These d-NSCs persist in the embryonic and adult brain germinal zones throughout life. The proliferation and self-

\footnotetext{
$\leftarrow$

Flk $1^{+/+}$p-NSC spheres but not in Flk $1^{-/-}$p-NSC spheres. GAPDH was used as a universal control. D, Nestin mRNA expression was detected in both Flk $1^{+/+}$and Flk $1^{-/-}$bulk p-NSC spheres at each of the 1, 10, and $100 \mathrm{ES}$ cell(s)/ $\mu \mathrm{l}$ starting densities. Brachyury mRNA expression was detected in Flk1 $1^{-1-}$ p-NSC spheres at all three of the ES cell starting densities. However, only the highest ES cell starting density produced Flk $1^{+/+}$p-NSC spheres with even weak expression of Brachyury mRNA. $\boldsymbol{E}$, Gene expression was assessed in single clonal $\mathrm{p}$-NSC spheres by RT-PCR. The top three bands for each single $\mathrm{p}$-NSC colony were from Flk $1^{+/+}$ sphere PCRs, and the bottom three bands for each single p-NSC colony were from Flk $1^{-1-}$ sphere PCRs. Only Nestin (and not Brachyury) mRNA expression was observed in each of the 16 of Flk $1^{+/+}$clonal p-NSC spheres. In contrast, 6 of 16 clonal Flk $1^{-1-}$ p-NSC spheres expressed Brachyury mRNA, but all of them (16 of 16) expressed Nestin mRNA. $\boldsymbol{F}$, Constitutive YFPexpressing ES cells were cocultured with either Flk $1^{+/+}$or Flk $1^{-1-}$ ES cells. The numbers of YFP p-NSC spheres was equivalent in both cocultures and at both YFP/Flk $1^{-1-}$ cell coculture ratios, but the nonfluorescent $\mathrm{Flk}^{-I-} \mathrm{p}-\mathrm{NSC}$ spheres showed the same threefold increase compared with nonfluorescent Flk $1^{+/+} \mathrm{p}$-NSC spheres, as was shown in non-cocultures in $\boldsymbol{B}$ (suggesting a cell-autonomous effect of the Flk1 mutation in the p-NSC sphere-forming cells). Data are mean \pm SEM. ${ }^{*} p<0.05$.
} 

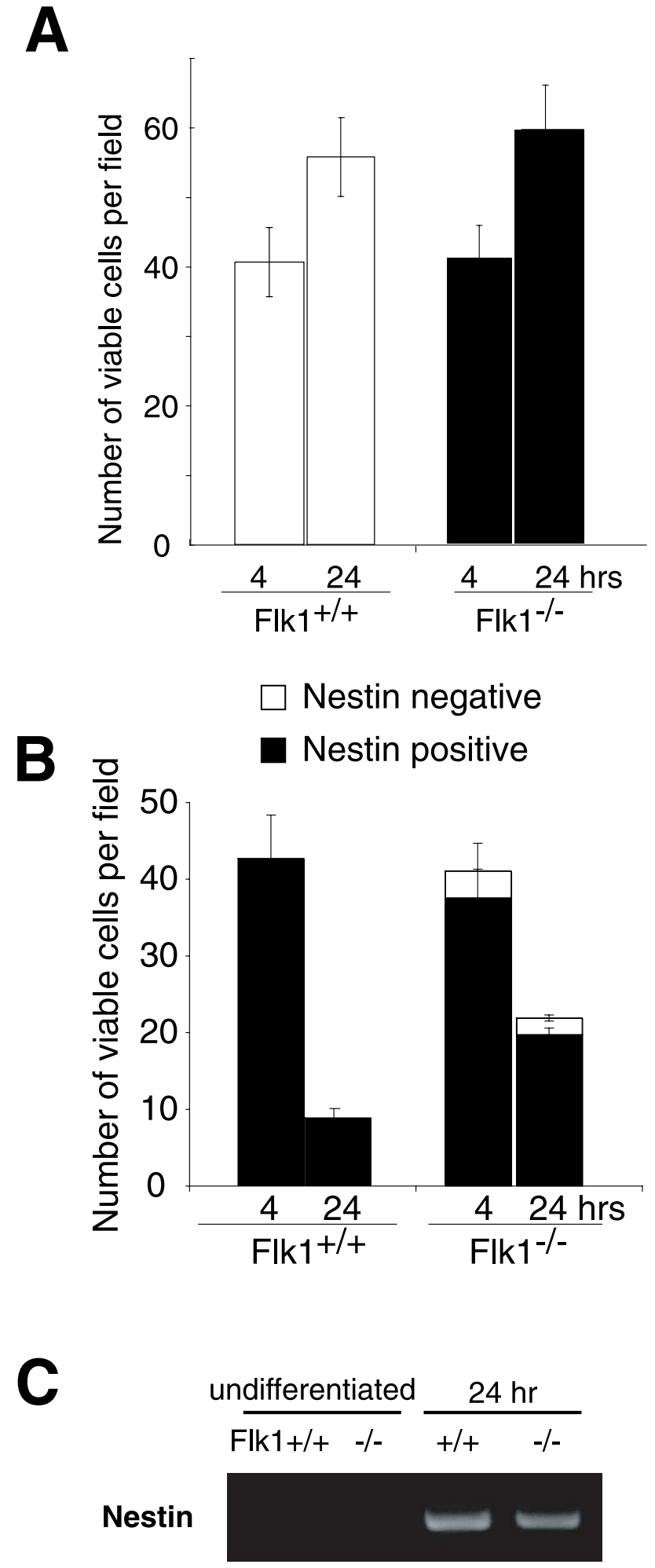

Figure 2. A, Dissociated undifferentiated ES cells were plated on gelatin-coated chamber slides at 10 cells/ $\mu$ l in ES culture media containing 10\% FBS. There were no significant differences in viable cells between $\mathrm{Flk} 1^{+/+}$and Flk1 $1^{-1-}$ undifferentiated ES cells at $4 \mathrm{~h}$ after plating. Although cell numbers were increased at $24 \mathrm{~h}$ after plating compared with $4 \mathrm{~h}, \mathrm{Flk} 1^{+/+}$and Flk1 ${ }^{-1-}$ undifferentiated ES cells showed similar numbers of viable cells (at $4 \mathrm{~h}, t_{(6)}=0.2, p>0.5$; at $24 \mathrm{~h}, t_{(6)}=0.3$, $p>0.5)$. $B$, Short-term differentiation assay from undifferentiated ES cell to $p$-NSC. Equal numbers of cells were present in both Flk $1^{+/+}$and Flk $1^{-/-}$cultures at the $4 \mathrm{~h}$ after plating. However, fewer cells were found in Flk $1^{+/+}$than Flk $1^{-/-}$cultures at $24 \mathrm{~h}$ after plating. A few Nestin-negative cells were observed only in Flk ${ }^{-1-}$ cultures at both 4 and $24 \mathrm{~h}$ after plating. C, RT-PCR of short-term differentiated ES cells. Nestin mRNA expression was detected in both Flk1 ${ }^{+/+}$and Flk1 ${ }^{-1-}$ p-NSC cells after $24 \mathrm{~h}$ of differentiation. Data are mean $\pm \mathrm{SEM}$. renewal of d-NSC is regulated by FGF2, EGF, and Notch ligands (Chiasson et al., 1999; Tropepe et al., 1999; Martens et al., 2000; Hitoshi et al., 2002). To investigate whether VEGF-A could act on d-NSCs, we first investigated the expression of Flk1 by RT-PCR. Flk1 mRNA expression was detected in adult brain d-NSCderived neurospheres as well as E14.5 d-NSC-derived embryonic neurospheres (Fig. 4A).

To test the function of VEGF-A signaling on d-NSCs, VEGF-A was added to clonal d-NSC cultures from E9.5 wild-type C57BL/6 mice. VEGF-A (100 ng/ml) enhanced neurosphere numbers $(0.64 \pm 0.37$ spheres per 5000 cells in control culture; $2.37 \pm 0.29$ spheres per 5000 cells in VEGF-A-treated culture; $t_{(3)}=4.9 ; p<$ $0.05)$. This result was exactly the opposite of the VEGF-A effect on p-NSCs (Fig. 3B). VEGF-A also enhanced neurosphere formation in cultures of adult d-NSCs in a dose-dependent manner (Fig. 4C). However, Brachyury mRNA was not induced by VEGF treatment of d-NSCs nor p-NSCs (Fig. 4B). There also was no change in Nestin and Flk1 mRNA expression produced by VEGF-A treatment on d-NSC (Fig. 4B). These results suggested that VEGF-A did not alter cell fate in p-NSCs and d-NSCs. The VEGF-A signaling inhibitor SU1498 (Shen et al., 1999) suppressed the number of clonal d-NSC-derived neurospheres at every dosage of VEGF-A tested, and even in the absence of VEGF-A addition to the culture media (Fig. 4C). Although SU1498 is reported to inhibit not only Flk1 downstream kinase activation but also other receptor tyrosine kinases (PDGF, EGF, or FGF), SU1498 still strongly inhibits on VEGF-A signaling cascade (Boguslawski et al., 2004). This later result suggests that neural precursor cells in neurosphere culture release endogenous VEGF-A and that this endogenous VEGF-A facilitates neurosphere formation. To check the ligand specificity of VEGF-A effects on d-NSC, two different VEGF-A inhibitors were added separately to E14.5 d-NSC neurosphere cultures. In contrast to the facilitatory effects of these inhibitors on p-NSC, the numbers of d-NSC were significantly decreased by both VEGF-A antibodies and Flk1/Fc chimeric soluble receptors (Fig. 4D). These results indicate that VEGF-A acts specifically on the Flk1 receptor in suppressing p-NSC formation. VEGF-A inhibitors also decreased d-NSC sphere numbers even in the absence of VEGF-A (Fig. 4D). These results further support that VEGF-A through Flk1 receptor specifically increased d-NSC sphere formation.

VEGF-A signaling in definitive neural stem cells acts to increase cell survival

Conditional inactivation of VEGF-A in the developing neuroectoderm [using the Nestin-Cre transgenic line (Tronche et al., 1999 ) and mice that carry a conditional null VEGF-A allele (Gerber et al., 1999)] resulted in dramatic phenotype involving loss of vascularity and subsequent hypoxia, resulting in the degeneration of the cerebral cortex and neonatal lethality (Haigh et al., 2003; Raab et al., 2004). To distinguish between the paracrine vascular role of VEGF-A and a potential direct neuronal autocrine role of VEGF-A contributing to this severe brain phenotype, Flk1 (through Nestin-Cre action) was conditionally inactivated in neural precursor cells (Haigh et al., 2003). Surprisingly, despite the deletion of Flk1 in the developing neural precursor cells, no major lethality was observed compared with the dramatic degenerative phenotypes associated with the conditional inactivation of VEGF-A in the nervous system. To more specifically address the role of Flk1 in NSC function, we investigated the effects of loss of VEGF-A signaling on d-NSCs by using the previously reported nervous system Flk1 conditional knock-out mice $\left(\mathrm{Nes}{ }^{\mathrm{Cre}} ; \mathrm{Flk} 1^{-1-}\right)$ (Haigh et al., 2003). Forebrain germinal 
zone tissue from adult $\mathrm{Nes}{ }^{\mathrm{Cre}} ; \mathrm{Flk}^{-/-}$ mice was dissociated in FGF2- and EGFcontaining, serum-free media. d-NSCderived clonal neurosphere numbers in the adult $\mathrm{Nes}^{\mathrm{Cre}} ; \mathrm{Flk}^{-1-}$ mice showed a dramatic $85 \%$ decrease compared with control mice (Fig. 5A). The sizes (diameters) of individual clonal primary neurospheres from adult $\mathrm{Nes}{ }^{\mathrm{Cr}} ; \mathrm{Flk}^{-1-}$ mice $(275 \pm 26 \mu \mathrm{m})$ were not significantly different $\left(t_{(5)}=0.7 ; p>0.5\right)$ from these of control Nes ${ }^{\mathrm{Cre}} ; \mathrm{Flk}^{+/-}$mice (263 \pm 35 $\mu \mathrm{m})$. These results suggest that d-NSCs are less likely to survive to adult stages in Nes ${ }^{\text {Cre }}$;Flk1 ${ }^{-1-}$ mice compared with control Nes ${ }^{\mathrm{Cr}}$;Flk1 ${ }^{-/-}$mice, but the proliferation of the $\mathrm{Nes}^{\mathrm{Cre}} ; \mathrm{Flk} 1^{-/-} \mathrm{d}$-NSCs that do survive was not compromised, suggesting that $\mathrm{Nes}^{\mathrm{Cre}} ; \mathrm{Flk}^{-1-}$ neural progenitor cells that make up most of the cells in the d-NSC spheres were unaffected by the Flk1 deficiency.

Even at E14.5, there is already a significant difference in the numbers of clonal d-NSCs derived from E14.5 $\mathrm{Nes}^{\mathrm{Cre}}$; Flk1 ${ }^{-1-}$ conditional knock-out mice compared with control Nes ${ }^{\mathrm{Cre}} ; \mathrm{Flk}{ }^{+/-}$mice (a decrease that is maintained through passaging from primary to tertiary spheres in vitro) (Fig. $5 B$ ). The similar passaging of the Flk1 knock-out and control adult neurospheres and the similar differentiation multipotentiality (into neuron and glia) of the single clonal adult neurospheres (Table 1) suggests that the loss of Flk1 has not modified these stem cell qualities (self-renewal and differentiation potential) of the d-NSCs, but rather affects the survival of the d-NSCs.

To ask whether the decreased neurosphere numbers in the $\mathrm{Nes}{ }^{\mathrm{Cre}} ; \mathrm{Flk} 1^{-1-}$ mice were caused by deficits in cell survival or cell proliferation, we acutely dissociated tissue directly from the adult mouse forebrain subependymal germinal zone and plated the cells on Matrigel-coated chamber slides. After $8 \mathrm{~h}$ incubation in serum-free, chemically defined media, cells were fixed and assessed for apoptosis and proliferation. Counts of total cell numbers revealed control $\mathrm{Nes}^{\mathrm{Cre}} ; \mathrm{Flk}^{+/-}$cells survived the overnight incubation significantly better than conditional knock-out $\mathrm{Ne}$ $\mathrm{s}^{\mathrm{Cre}} ;$ Flk ${ }^{-/-}$cells (Fig. 5 C). Moreover, there were more apoptotic terminal deoxynucleotidyl transferase-mediated biotinylated UTP nick end labeling (TUNEL)-positive cells in the overnight Nes ${ }^{\mathrm{Cre}} ; \mathrm{Flk}^{-/-}{ }^{-1}$ cultures than in the control Nes ${ }^{\mathrm{Cre}} ; \mathrm{Flk1}{ }^{+/-} \mathrm{cul}^{-}$ tures (Fig. $5 C$ ). However, $\sim 70 \%$ of the cells were proliferating, $\mathrm{Ki}-67$-positive cells in both the $\mathrm{Nes}^{\mathrm{Cre}} ; \mathrm{Flk}^{-1-}$ and control cultures (Fig. 5C). These observations suggest that Flk1 signaling in neural cells directly isolated from the adult mouse forebrain germinal zone increases cell survival (but does not affect neural precursor proliferation) and imply that Flk1 signaling may increase d-NSC clonal colony numbers by increasing the cell survival of d-NSCs.

Lack of VEGF-A signaling decreases the definitive neural stem cells derived from the enhanced primitive neural stem cell population

The results so far suggest two separate effects of VEGF-A signaling: VEGF-A signaling decreases p-NSC survival and increases d-NSC survival. Because of the fact that ES-derived LIF- dependent p-NSCs can mature directly into FGF-dependent d-NSCs after single neurosphere suspension culture passaging (Tropepe et al., 2001; Hitoshi et al., 2004), we asked whether the two separate and opposite effects of VEGF-A signaling could be demonstrated within the same lineage in vitro. First, Flk1 ${ }^{-1-}$ primary clonal p-NSC spheres (derived directly from single mutant ES cells) showed the same threefold increase (that was described above) compared with primary p-NSC spheres derived directly from single Flk1 ${ }^{+/+}$ES cells. However, when these ES cell-derived p-NSC clonal neurosphere colonies were dissociated and passaged as d-NSCs, Flk1 ${ }^{+/+}$d-NSC neurosphere formation was significantly greater than Flk1 ${ }^{-1-}$ secondary d-NSC neurosphere formation in FGF2- and B27-containing media (Fig. 5D). A decrease in the number of secondary (d-NSC) neurospheres from the dissociation of single Flk $1^{-/-}$compared with Flk $1^{+/+}$ ES cell derived clonal p-NSC neurospheres (Fig. 5A), confirmed the bulk dissociation results. In contrast, the numbers of passaged clonal d-NSC neurosphere colonies derived from Flt1 ${ }^{-/-}$ p-NSCs were not changed compared with d-NSC colonies derived from Flt $1^{+/+}$p-NSCs (Fig. $5 D$ ), suggesting a specific action of Flk1 and not Flt1 on d-NSCs. Although Flk1 mRNA was expressed only in Flk1 ${ }^{+/+}$and not Flk1 $-/-$cells, the mRNAs for the VEGF-A ligand and Flt1 were expressed both in the Flk1 ${ }^{+/+}$ and Flk $1^{-/-}$ES cell-derived p-NSC primary neurosphere colonies and also in the Flk1 ${ }^{+/+}$and Flk $1^{-/-}$secondary d-NSC neurosphere colonies derived from primary p-NSCs (Fig. $5 E$ ). The opposite effects of the loss of VEGF-A signaling on ES cellderived primary $\mathrm{p}$-NSC versus secondary d-NSC neurosphere formation within the same in vitro neural lineage parallel the opposite effects of loss of VEGF-A signaling on p-NSCs derived from E7.5 embryos (increased) versus d-NSC-derived from later embryos or adult brains (decreased).

\section{NF- $\kappa$ B inhibits p-NSC survival and d-NSC cell death}

$\mathrm{NF}-\kappa \mathrm{B}$ is a downstream effector of VEGF-A signaling (Santos and Dias, 2004) and has two effects on cell death (Barkett and Gilmore, 1999). NF- $\kappa \mathrm{B}$ increases the survival of immature 


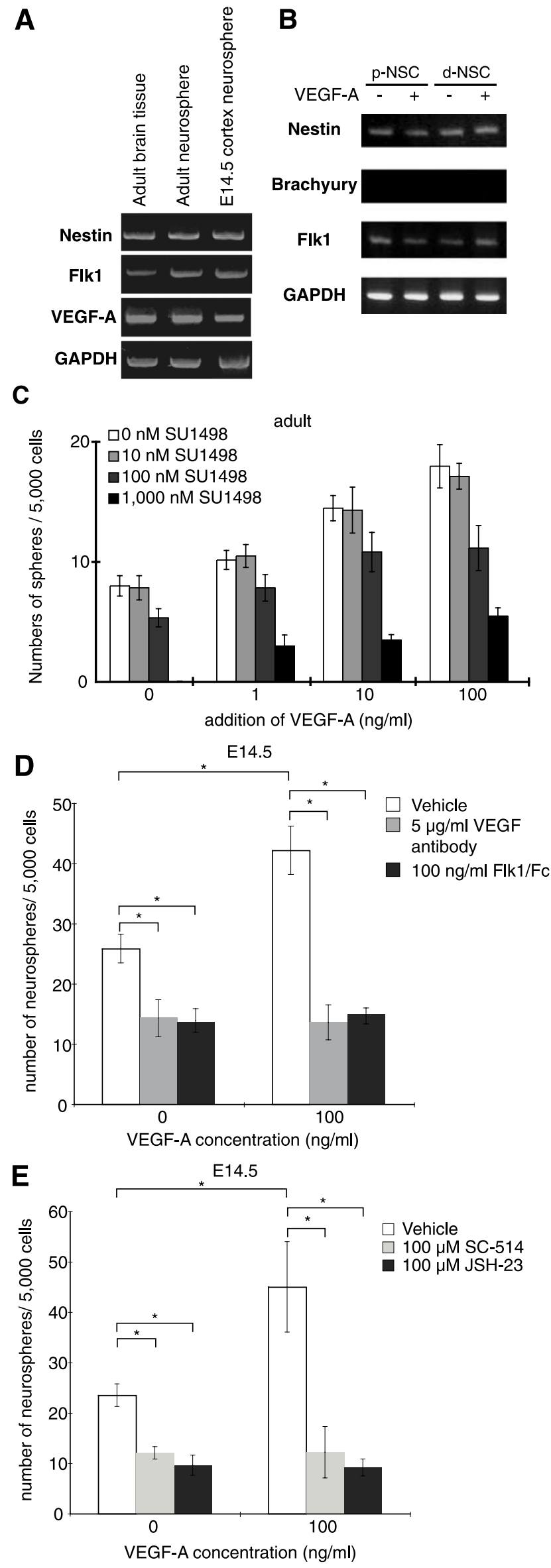

B-lymphocytes (Sonenshein, 1997) but also induces cell death by activating expression of Fas ligand (and the tumor necrosis factor death receptor family) after T-cell receptor engagement (Matsui et al., 1998).

The expression of NF- $\kappa \mathrm{B}$ was observed in both p-NSCs and d-NSCs derived from both Flk1 $1^{+/+}$and Flk $1^{-1-}$ cells (Fig. 5E). To investigate whether NF- $\kappa \mathrm{B}$ regulates cell death/survival downstream of VEGF-A signaling, NF- $\kappa$ B inhibitors were added to both p-NSC and d-NSC cultures. SC-514 inhibits the kinase activity of $\mathrm{I} \kappa \mathrm{B}$ kinase, a part of the NF- $\kappa \mathrm{B}$ complex (Kishore et al., 2003). JSH-23 suppresses the DNA binding of NF- $\kappa \mathrm{B}$ (Shin et al., 2004). These two types of NF- $\kappa$ B inhibitors (SC-514 and JSH-23) were added to cultures derived from wild-type R1 ES cells. The numbers of p-NSCs were significantly increased by both SC-514 and JSH-23 (Fig. $3 C$ ). These NF- $\kappa \mathrm{B}$ inhibitors also increased p-NSC numbers in the absence of VEGF-A (Fig. $3 C$ ).

In contrast, E14.5 d-NSC neurosphere numbers were decreased by the two NF- $\kappa$ B inhibitors (Fig. $4 E$ ). The NF- $\kappa$ B inhibitors also decreased p-NSC numbers in the absence of VEGF-A. (Fig. $4 E$ ). These two opposite direction effects of NF- $\kappa \mathrm{B}$ inhibitors on p-NSCs versus d-NSCs parallel those seen with our manipulations of VEGF-A signaling.

\section{Discussion}

Single ES cells in minimal, serum-free media will default to p-NSCs (Tropepe et al., 2001; Hitoshi et al., 2004; Smukler et al., 2006). However, under these minimal culture conditions, many of the p-NSC then die. The present results show that VEGF-A signaling actually promotes the death of these p-NSCs (summary figure in supplemental material, available at www.jneurosci.org). On the other hand, both in vitro and in vivo, the survival of the embryonic d-NSCs that arise from p-NSCs (and the survival of adult d-NSCs) is promoted by VEGF-A signaling (summary figure in supplemental material, available at www.jneurosci.org). These data suggest cell death/survival effects of VEGF-A signaling on p-NSCs and d-NSCs, rather than cell proliferation or fate change effects. There is no evidence suggesting that VEGF-A regulates the transition between p-NSCs and d-NSCs. Indeed, VEGF-A signaling decreases the numbers of p-NSCs, so these

\footnotetext{
$\leftarrow$

Figure 4. A, Adult brain tissue as well as d-NSC-derived clonal neurospheres from the adult brain express Flk1 mRNA. Clonal E14.5 brain neurospheres also expressed Flk1 mRNA. Nestin and control GAPDH mRNAs were expressed in adult brain tissue, clonal adult brain neurospheres, and clonal E14.5 brain neurospheres. $\boldsymbol{B}$, Nestin and Flk1 mRNA expression were not changed by VEGF-A treatment of either p-NSCs or d-NSCs. Moreover, Brachyury mRNA expression was not induced by VEGF-A treatment of either p-NSCs or d-NSCS. C, Increasing concentrations of VEGF-A enhanced the formation of neurospheres from adult mouse d-NSCs. Moreover, this VEGF-A-induced increase in neurospheres was suppressed by the addition of SU1498, a VEGF-A signaling inhibitor. SU1498 also decreased the number of neurospheres in the absence of VEGF-A in the culture media. D, The enhanced numbers of E14.5 d-NSC spheres produced by VEGF-A were blocked by the addition of two VEGF-A inhibitors, VEGF-A antibodies and Flk1/Fcsoluble chimeric receptors. There was a significant interaction of VEGF-A dose and blocker $\left(F_{(3,20)}=36.86 ; p<0.05\right)$. Multiple comparison tests revealed that both VEGF-A antibodies $(p<0.05)$ and $\mathrm{Flk} 1 / \mathrm{Fc}$ receptors $(p<0.05)$ decreased $d-N S C$ numbers in the presence of VEGF-A compared with VEGF-A treatment alone. Furthermore, in the absence of VEGF-A, both VEGF-A antibodies $(p<0.05)$ and Flk1/Fc chimeric receptors $(p<0.05)$ decrease $d-N S C$ numbers compared with their vehicle controls. $\boldsymbol{E}$, The increased numbers of $d$-NSC spheres in the presence of VEGF-A was blocked by two different NF- $\kappa$ B inhibitors, SC-514 and JSH-23. There was a significant interaction of VEGF-A dose and NF- $\kappa$ B inhibitor $\left(F_{(4,56)}=18.3 ; p<0.05\right)$. Multiple comparison tests revealed that both SC $-514(p<0.05)$ and JSH-23 $(p<0.05)$ decreased $d$-NSC numbers in the presence of VEGF-A compared with VEGF-A treatment alone. Moreover, in the absence of VEGF-A, both SC-514 $(p<0.05)$ and JSH-23 $(p<0.05)$ produced a decrease in p-NSC numbers compared with their vehicle controls. Data are mean \pm SEM. ${ }^{*} p<0.05$.
} 

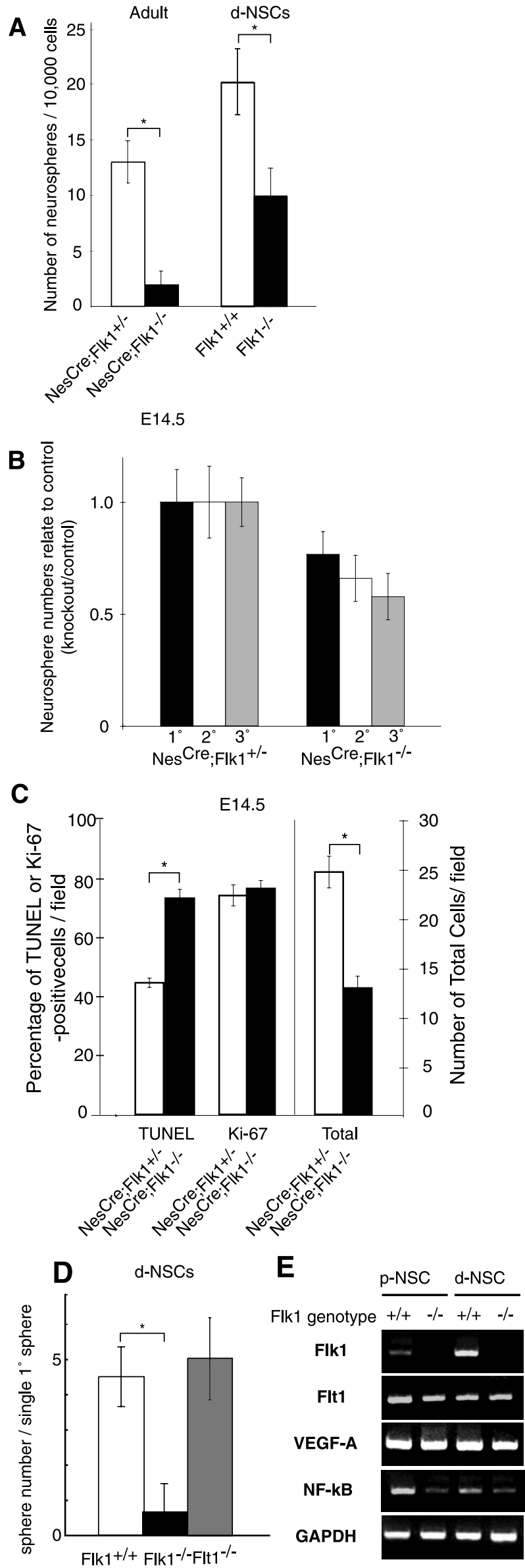

fewer p-NSCs cannot give rise to the increased survival of d-NSCs that is produced by VEGF-A signaling. Manipulations of NF- $\kappa \mathrm{B}$ (a known downstream effector of VEGF-A signaling) (Santos and Dias, 2004) also produce opposite effects on p-NSCs versus $\mathrm{d}$-NSCs. Moreover, the effects of NF- $\kappa \mathrm{B}$ manipulations were seen in the presence or absence of VEGF-A, suggesting that NF- $\kappa B$ acts downstream of VEGF-A signaling in the control of neural stem cell survival as well (summary figure in supplemental material, available at www.jneurosci.org).

The opposite effects of VEGF-A signaling on p-NSCs and d-NSCs both operate through a cell survival mechanism rather than through another cell biological process. VEGF-A signaling is not involved in the default fate change from an ES cell to a p-NSC. Four hours after being placed in serum- and growth factor-free media, similar numbers of Nestin-negative Flk $1^{-/-}$and Flk1 ${ }^{+/+}$ undifferentiated ES cells had defaulted to a Nestin-positive p-NSC fate. However, by $24 \mathrm{~h}$ in the same conditions, three times more Flk $1^{-1-}$ p-NSCs were alive than Flk $1^{+/+}$p-NSCs. Similarly, but in the opposite direction, many more apoptotic, TUNEL-positive $\mathrm{Nes}^{\mathrm{Cre}} ; \mathrm{Flk}^{-1-}$ than $\mathrm{Nes}^{\mathrm{Cre}} ; \mathrm{Flk1}^{+/-}$adult neural precursor cells were observed $24 \mathrm{~h}$ after dissociation of the forebrain germinal zone. These data suggest that VEGF-A signaling controls the numbers of NSC through the regulation of cell survival. VEGF-A signaling does not appear to affect the proliferation of d-NSC because (1) the numbers of Ki-67-positive, primary adult neural precursor cells are similar in the $\mathrm{Nes}^{\mathrm{Cre}}$; $\mathrm{Flk} 1^{+-}$and $\mathrm{Nes}{ }^{\mathrm{Cre}} ; \mathrm{Flk} 1^{-1-}$ short-term cultures, and (2) the individual neurospheres that proliferate clonally from both p-NSCs and d-NSCs of both the Flk $1^{+/+}$and Flk $1^{-/-}$genotypes are of similar sizes, and thus consist of similar numbers of cells.

p-NSC spheres are derived clonally from single p-NSCs (Tropepe et al., 2001; Smukler et al., 2006). Thus, the numbers of p-NSC spheres are taken as a direct measure of the number of p-NSCs. The p-NSC spheres are made up of many neural progenitors and only a few p-NSCs that passage as d-NSCs. Given that the Flk1 ${ }^{+/+}$and Flk1 ${ }^{-/-}$p-NSC spheres are similar in size (and that most of the cells in the spheres are progenitors), this suggests that VEGF-A signaling had little effect on neural progenitor cell survival, as well as no effect on cell lineage transitions (Fig. 4B). Moreover, because it is not possible to passage clonal p-NSCs as p-NSCs at this point, we cannot test a role for VEGF-A signaling in the maintenance of p-NSCs.

Brachyury mRNA expression in p-NSCs derived from Flk1 ${ }^{-/-}$(but not Flk1 ${ }^{+/+}$) ES cells reveals not only a mesodermal

$\leftarrow$

Figure 5. A, The numbers of neurospheres from the forebrain germinal zone of adult Nes ${ }^{\text {Cre. }}$; Flk1 $1^{-1-}$ mice were decreased dramatically compared with control Nes ${ }^{\text {Cre }}$; Flk $1^{+/-}$mice $\left(t_{(4)}=4.2 ; p<0.05\right)$. Although more clonal, primary $\mathrm{p}$-NSC-derived neurospheres emerge from Flk $1^{-1-}$ compared with Flk $1^{+/+}$ES cultures, fewer clonal, secondary d-NSC Flk $1^{-1-}$ than Flk ${ }^{+/+}$spheres arose in FGF2 and B27 from the primary p-NSC sphere dissociations $\left(t_{(3)}\right.$ $=4.2 ; p<0.05) . B$, There were significant decreases in the numbers of primary and passaged clonal d-NSCs derived from E14.5 Nes ${ }^{\text {Cre }}$;Flk1 ${ }^{-1-}$ conditional knock-out mice compared with control Nes ${ }^{\text {Cre }}$;Flk $1^{+1-}$ mice. C, Acute dissociation assays of adult forebrain germinal zone cells. The total numbers of Nes ${ }^{\text {Cre; }}$; Flk $1^{-1-}$ cells were fewer than Nes ${ }^{\text {re }}$; Flk $1^{+-}$cells after $8 \mathrm{~h}$ of incubation (right; $t_{(4)}=5.2 ; p<0.05$ ). More apoptotic, TUNEL-positive cells were seen among the Nes ${ }^{\text {Cre, }}$;Flk $1^{-1-}$ cells than among the control Nes ${ }^{\text {Cre; }}$; $F k 1^{+/-}$cells (left; $t_{(4)}=6.1 ; p<0.05$ ). However, numbers of proliferating Ki-67-positive cells were similar in Nes ${ }^{\mathrm{Cr}}$; $\mathrm{Flk} 1^{-1-}$ and control $\mathrm{Nes}^{\mathrm{Cr}}$; Fllk $1^{+/-} 8 \mathrm{~h}$ cultures (middle; $t_{(4)}=0.4 ; p>0.5$ ). D, Single primary p-NSC-derived d-NSC neurosphere passaging confirmed the decrease in secondary Flk1 ${ }^{-1-}$ compared with wild-type d-NSC neurospheres $\left(t_{(3)}=3.3 ; p<0.05\right)$, seen with bulk passaging $(A)$. Similar numbers of clonal d-NSC neurospheres were produced by Flt1 $1^{-1-}$ and wild-type cells $\left(t_{(4)}=0.3 ; p>0.5\right)$. $\boldsymbol{E}$, Both $\mathrm{p}$-NSCs and d-NSCs derived from Flk $1^{+/+}$or Flk $1^{-1-}$ ES cells expressed Flt1, NF- $\kappa B$, and VEGF-A mRNAs. Data are mean \pm SEM. ${ }^{*} p<0.05$. 
character, but we suggest also a less committed p-NSC phenotype. Although our data suggest that the loss of Flk1 affects both p-NSC survival and pluripotency, it is difficult to exclude the possibility that one phenotype is a direct effect of the other. The Brachyury expression in only some clonal Flk1 ${ }^{-1-}$ p-NSC spheres (Fig. 1E) might suggest that the survival and pluripotency effects of loss of VEGF-A signaling can be dissociated, but this also may reflect simple variation of Brachyury expression in the mutant clones. It remains possible that the Flk $1^{-1-}$ mutant p-NSC population is heterogeneous, but there is no evidence other than the variable expression of Brachyury that speaks to this point.

Although Notch signaling is essential for the maintenance of d-NSCs (Hitoshi et al., 2002, 2004), it is doubtful that VEGF-A signaling works through a Notch-like self-renewal mechanism, because Flk1 mutant d-NSCs do not show the significant decrease over in vitro passaging that is seen with the in vitro passaging of Notch pathway loss of function NSC mutants (Hitoshi et al., 2002). Furthermore, the similar neuronal and glial differentiation from Flk1 ${ }^{+/+}$and Flk1 ${ }^{-/-}$p-NSCs also suggests a different mechanism of action from Notch signaling in which increased neuronal and glial differentiation is seen from clonal NSCs (Hitoshi et al., 2002). Therefore, we conclude that the VEGF-A signaling effects on NSC survival provide the most parsimonious single factor, cell biological mechanism to explain VEGF-A pathway gain and loss of function effects.

Both clonal p-NSC and d-NSC colony formation were similar when starting with wild-type and Flt1 ${ }^{-1-}$ ES cells. These data suggest that the VEGF-A effects on p-NSCs and d-NSCs are working through Flk1, and not Flt1, receptors and reveal that Flt1 is less important than Flk1 in neural stem cell regulation.

Wild-type ES cell-derived p-NSCs have the potential to differentiate into not only neural tissues but also other non-neural lineages when they are used to make mouse E3.5 blastocyst chimeras (Tropepe et al., 2001). Similarly, in high-density ES cell culture, non-neural markers can appear in the wild-type p-NSCderived neurospheres that only express neural markers when they arise from the low-density cultures. This suggests that the potential of wild-type p-NSCs to give rise to non-neural cells is activated only in especially favorable conditions. Indeed, because VEGF-A signaling suppresses the potential of clonal p-NSCs to differentiate into non-neural cell types, we suggest that the removal of VEGF-A signaling may be one of those especially favorable conditions. Adult mouse brain-derived d-NSCs have been reported to differentiate into hematopoietic and other nonneural cells at very low frequencies (Bjornson et al., 1999; Clarke et al., 2000), but our results at least with wild-type NSCs have not replicated these d-NSC non-neural potentials (Morshead et al., 2002; T. Wada, unpublished data).

VEGF-A can be secreted by primitive and visceral endoderm as early as E5.5-E8.0 in the mouse embryo, at the same stage when p-NSCs can be observed in the epiblast and forming neuroectoderm (Miquerol et al., 1999). This result raises the possibility that VEGF-A released by non-neural epithelial cells may act on p-NSCs in vivo. However, our observation of VEGF-A and Flk1 mRNA expression in undifferentiated ES cells suggests even earlier embryonic effects, in which VEGF-A signaling is part of the mechanism (in addition to TGF $\beta$ signaling) (Tropepe et al., 2001) that suppresses p-NSC formation and survival in vitro before neural plate formation of Nestin ${ }^{+}$cells is first detected at E7.5. Although undifferentiated ES cells in hypoxic conditions respond to VEGF-A as a survival factor (Brusselmans et al., 2005), this finding is different from the present results. The previous effects were seen only under hypoxic conditions and only on undifferentiated ES cells, whereas the present results were specific to primitive neural stem cells under nonhypoxic conditions. There also are several possible VEGF-A sources that might permit the endogenous regulation of d-NSC in both embryonic and adult brain. First, VEGF-A is expressed by d-NSC-derived clonal neurospheres (Maurer et al., 2003) and also acts as a survival factor for neural precursor cells (not distinguishing between stem and progenitor cells) in vitro and in vivo (Schanzer et al., 2004). Second, the endothelial cells of blood capillaries in the neighborhood of neural precursor cells (Palmer et al., 2000; Shen et al., 2004) allow for a paracrine action on d-NSCs (Haigh et al., 2003). Reactive astrocytes also are a source of VEGF-A when injury occurs (Chow et al., 2001). Certainly, non-VEGF-A-mediated signals from endothelial cells regulate d-NSC behaviors as well (Shen et al., 2004). The dramatic decrease of in vitro clonal d-NSC-derived neurosphere number from the brains of $\mathrm{Nes}^{\mathrm{Cre}}$; Flk $1^{-/-}$mice seems at variance with the finding of only relatively minor phenotypes in the embryonic brains of $\mathrm{Nes}^{\mathrm{Cre}}$; $\mathrm{Flk} 1^{-1-}$ mice (Haigh et al., 2003). Presumably, the minimal culture conditions used to isolate NSCs in vitro emphasize the cell death effects of manipulating VEGF-A signaling. In contrast, such cell death effects in the brain of the $\mathrm{Nes}^{\mathrm{Cre}} ; \mathrm{Flk} 1^{-/-}$mice in vivo may be compensated by other growth and survival factors.

Although there are differences in the growth factor dependency [LIF, FGF2, TGF $\beta$ (Tropepe et al., 2001) and Notch signaling (Hitoshi et al., 2004)] of p-NSCs compared with d-NSCs, the present report reveals completely opposite survival effects of a single growth factor (VEGF-A) on these two NSC types. Indeed, the separate VEGF-A survival effects on the p-NSCs versus d-NSCs appear to be independent of any direct effects on fate changes, proliferation, or self-renewal and appear to be specific effects on NSC as opposed to other cells in the neural lineage.

\section{References}

Barkett M, Gilmore TD (1999) Control of apoptosis by Rel/NF-kappaB transcription factors. Oncogene 18:6910-6924.

Bjornson CR, Rietze RL, Reynolds BA, Magli MC, Vescovi AL (1999) Turning brain into blood: a hematopoietic fate adopted by adult neural stem cells in vivo. Science 283:534-537.

Boguslawski G, McGlynn PW, Harvey KA, Kovala AT (2004) SU1498, an inhibitor of vascular endothelial growth factor receptor 2, causes accumulation of phosphorylated ERK kinases and inhibits their activity in vivo and in vitro. J Biol Chem 279:5716-5724.

Brusselmans K, Bono F, Collen D, Herbert JM, Carmeliet P, Dewerchin M (2005) A novel role for VEGF as an autocrine survival factor for embryonic stem cells during hypoxia. J Biol Chem 280:3493-3499.

Chiasson BJ, Tropepe V, Morshead CM, van der Kooy D (1999) Adult mammalian forebrain ependymal and subependymal cells demonstrate proliferative potential, but only subependymal cells have neural stem cell characteristics. J Neurosci 19:4462-4471.

Chow J, Ogunshola O, Fan SY, Li Y, Ment LR, Madri JA (2001) Astrocytederived VEGF mediates survival and tube stabilization of hypoxic brain microvascular endothelial cells in vitro. Brain Res Dev Brain Res 130:123-132.

Clarke DL, Johansson CB, Wilbertz J, Veress B, Nilsson E, Karlstrom H, Lendahl U, Frisen J (2000) Generalized potential of adult neural stem cells. Science 288:1660-1663.

Cross MJ, Dixelius J, Matsumoto T, Claesson-Welsh L (2003) VEGFreceptor signal transduction. Trends Biochem Sci 28:488-494.

Dumont DJ, Fong GH, Puri MC, Gradwohl G, Alitalo K, Breitman ML (1995) Vascularization of the mouse embryo: a study of flk-1, tek, tie, and vascular endothelial growth factor expression during development. Dev Dyn 203:80-92.

Ema M, Faloon P, Zhang WJ, Hirashima M, Reid T, Stanford WL, Orkin S, Choi K, Rossant J (2003) Combinatorial effects of Flk1 and Tall on 
vascular and hematopoietic development in the mouse. Genes Dev 17:380-393.

Fabel K, Tam B, Kaufer D, Baiker A, Simmons N, Kuo CJ, Palmer TD (2003) VEGF is necessary for exercise-induced adult hippocampal neurogenesis. Eur J Neurosci 18:2803-2812.

Fong GH, Klingensmith J, Wood CR, Rossant J, Breitman ML (1996) Regulation of flt-1 expression during mouse embryogenesis suggests a role in the establishment of vascular endothelium. Dev Dyn 207:1-10.

Fong GH, Zhang L, Bryce DM, Peng J (1999) Increased hemangioblast commitment, not vascular disorganization, is the primary defect in flt-1 knock-out mice. Development 126:3015-3025.

Gage FH (2000) Mammalian neural stem cells. Science 287:1433-1438.

Gerber HP, Hillan KJ, Ryan AM, Kowalski J, Keller GA, Rangell L, Wright BD, Radtke F, Aguet M, Ferrara N (1999) VEGF is required for growth and survival in neonatal mice. Development 126:1149-1159.

Haigh JJ, Morelli PI, Gerhardt H, Haigh K, Tsien J, Damert A, Miquerol L, Muhlner U, Klein R, Ferrara N, Wagner EF, Betsholtz C, Nagy A (2003) Cortical and retinal defects caused by dosage-dependent reductions in VEGF-A paracrine signaling. Dev Biol 262:225-241.

Hitoshi S, Alexson T, Tropepe V, Donoviel D, Elia AJ, Nye JS, Conlon RA, Mak TW, Bernstein A, van der Kooy D (2002) Notch pathway molecules are essential for the maintenance, but not the generation, of mammalian neural stem cells. Genes Dev 16:846-858.

Hitoshi S, Seaberg RM, Koscik C, Alexson T, Kusunoki S, Kanazawa I, Tsuji S, van der Kooy D (2004) Primitive neural stem cells from the mammalian epiblast differentiate to definitive neural stem cells under the control of Notch signaling. Genes Dev 18:1806-1811.

Jin K, Zhu Y, Sun Y, Mao XO, Xie L, Greenberg DA (2002) Vascular endothelial growth factor (VEGF) stimulates neurogenesis in vitro and in vivo. Proc Natl Acad Sci USA 99:11946-11950.

Kishore N, Sommers C, Mathialagan S, Guzova J, Yao M, Hauser S, Huynh K, Bonar S, Mielke C, Albee L, Weier R, Graneto M, Hanau C, Perry T, Tripp CS (2003) A selective IKK-2 inhibitor blocks NF-kappa B-dependent gene expression in interleukin-1 beta-stimulated synovial fibroblasts. J Biol Chem 278:32861-32871.

Martens DJ, Tropepe V, van Der Kooy D (2000) Separate proliferation kinetics of fibroblast growth factor-responsive and epidermal growth factor-responsive neural stem cells within the embryonic forebrain germinal zone. J Neurosci 20:1085-1095.

Matsui K, Fine A, Zhu B, Marshak-Rothstein A, Ju ST (1998) Identification of two NF-kappa B sites in mouse CD95 ligand (Fas ligand) promoter: functional analysis in T cell hybridoma. J Immunol 161:3469-3473.

Maurer MH, Tripps WK, Feldmann Jr RE, Kuschinsky W (2003) Expression of vascular endothelial growth factor and its receptors in rat neural stem cells. Neurosci Lett 344:165-168.

Miquerol L, Gertsenstein M, Harpal K, Rossant J, Nagy A (1999) Multiple developmental roles of VEGF suggested by a LacZ-tagged allele. Dev Biol 212:307-322.

Morshead CM, Benveniste P, Iscove NN, van der Kooy D (2002) Hematopoietic competence is a rare property of neural stem cells that may depend on genetic and epigenetic alterations. Nat Med 8:268-273.

Palmer TD, Willhoite AR, Gage FH (2000) Vascular niche for adult hippocampal neurogenesis. J Comp Neurol 425:479-494.
Raab S, Beck H, Gaumann A, Yuce A, Gerber HP, Plate K, Hammes HP, Ferrara N, Breier G (2004) Impaired brain angiogenesis and neuronal apoptosis induced by conditional homozygous inactivation of vascular endothelial growth factor. Thromb Haemost 91:595-605.

Santos SC, Dias S (2004) Internal and external autocrine VEGF/KDR loops regulate survival of subsets of acute leukemia through distinct signaling pathways. Blood 103:3883-3889.

Schanzer A, Wachs FP, Wilhelm D, Acker T, Cooper-Kuhn C, Beck H, Winkler J, Aigner L, Plate KH, Kuhn HG (2004) Direct stimulation of adult neural stem cells in vitro and neurogenesis in vivo by vascular endothelial growth factor. Brain Pathol 14:237-248.

Seaberg RM, van der Kooy D (2003) Stem and progenitor cells: the premature desertion of rigorous definitions. Trends Neurosci 26:125-131.

Shalaby F, Rossant J, Yamaguchi TP, Gertsenstein M, Wu XF, Breitman ML, Schuh AC (1995) Failure of blood-island formation and vasculogenesis in Flk-1-deficient mice. Nature 376:62-66.

Shalaby F, Ho J, Stanford WL, Fischer KD, Schuh AC, Schwartz L, Bernstein A, Rossant J (1997) A requirement for Flk1 in primitive and definitive hematopoiesis and vasculogenesis. Cell 89:981-990.

Shen BQ, Lee DY, Zioncheck TF (1999) Vascular endothelial growth factor governs endothelial nitric-oxide synthase expression via a KDR/Flk-1 receptor and a protein kinase C signaling pathway. J Biol Chem 274:33057-33063.

Shen Q, Goderie SK, Jin L, Karanth N, Sun Y, Abramova N, Vincent P, Pumiglia K, Temple S (2004) Endothelial cells stimulate self-renewal and expand neurogenesis of neural stem cells. Science 304:1338-1340.

Shin HM, Kim MH, Kim BH, Jung SH, Kim YS, Park HJ, Hong JT, Min KR, Kim Y (2004) Inhibitory action of novel aromatic diamine compound on lipopolysaccharide-induced nuclear translocation of NF-kappaB without affecting IkappaB degradation. FEBS Lett 571:50-54.

Smukler SR, Runciman SB, Xu S, van der Kooy D (2006) Embryonic stem cells assume a primitive neural stem cell fate in the absence of extrinsic influences. J Cell Biol 172:79-90.

Sonenshein GE (1997) Rel/NF-kappa B transcription factors and the control of apoptosis. Semin Cancer Biol 8:113-119.

Sun Y, Jin K, Childs JT, Xie L, Mao XO, Greenberg DA (2006) Vascular endothelial growth factor-B (VEGFB) stimulates neurogenesis: evidence from knockout mice and growth factor administration. Dev Biol 289:329-335.

Tronche F, Kellendonk C, Kretz O, Gass P, Anlag K, Orban PC, Bock R, Klein R, Schutz G (1999) Disruption of the glucocorticoid receptor gene in the nervous system results in reduced anxiety. Nat Genet 23:99-103.

Tropepe V, Sibilia M, Ciruna BG, Rossant J, Wagner EF, van der Kooy D (1999) Distinct neural stem cells proliferate in response to EGF and FGF in the developing mouse telencephalon. Dev Biol 208:166-188.

Tropepe V, Hitoshi S, Sirard C, Mak TW, Rossant J, van der Kooy D (2001) Direct neural fate specification from embryonic stem cells: a primitive mammalian neural stem cell stage acquired through a default mechanism. Neuron 30:65-78.

van der Kooy D, Weiss S (2000) Why stem cells? Science 287:1439-1441.

Wurmser AE, Nakashima K, Summers RG, Toni N, D'Amour KA, Lie DC, Gage FH (2004) Cell fusion-independent differentiation of neural stem cells to the endothelial lineage. Nature 430:350-356. 